\title{
Association of Tumor Necrosis Factor- $\alpha$ Gene Promoter Polymorphisms with Periodontitisin Type II Diabetic Syrian Population
}

Faten $\mathrm{Kafa}^{1 *}$, Ali Abou Sulaiman ${ }^{2}$, Shaden Haddad ${ }^{1}$

${ }^{1}$ Biochemistry and Microbiology Department, Faculty of Pharmacy, Damascus University, Syria.

${ }^{2}$ Periodontology Department, Faculty of Dentistry, Damascus University, Syria.

\section{Abstract}

Objectives: Tumor necrosis factor- $\alpha(\mathrm{TNF}-\alpha)$ is a proinflammatory cytokine that can regulate periodontal tissue health and insulin-sensitive glucose uptake. TNF- $\alpha$ gene polymorphisms $-857 \mathrm{C} / \mathrm{T}$ and $-1031 \mathrm{~T} / \mathrm{C}$ could influence periodontitisand type II diabetes mellitus (DM). The goal of this studyis to evaluate the association between TNF- $\alpha$ gene polymorphisms $(-857 \mathrm{C} / \mathrm{T}$ and $-1031 \mathrm{~T} / \mathrm{C}$ ) and both diseases in the Syrian population.

Design: 180 subjects were recruited and allocated into four groups: $\mathrm{H}=$ healthy control, $\mathrm{DM}=$ diabetes mellitus, $\mathrm{ChP}=$ chronic periodontitis and ChPDM = chronic periodontitiswith DM.TNF- $\alpha$ SNPswereanalyzed by restriction fragment length polymorphism (RFLP-PCR) technique.

Results: $857 \mathrm{C} / \mathrm{T}$ gene polymorphism showed a lack of association with susceptibility to $\mathrm{ChP}$, and $\mathrm{T}$ allele frequency was significantly higher in DM (adjusted OR 3.116, 95\% CI: 1.184- 8.2, p = 0.019), Whereas, -1031CC genotype hadmore frequency in ChPDM group, and $\mathrm{C}$ allele has the higher probability in both diseases $(\mathrm{OR}=3.013$, CI: $1.275-7.117, \mathrm{P}=0.011)$.

Conclusion: Thisstudy data suggested that the $\mathrm{TNF}-\alpha$ polymorphism $-1031 \mathrm{~T} / \mathrm{C}$ couldbe a potentialrisk factors of periodontitis, but there were no association between $-857 \mathrm{C} / \mathrm{T}$ and periodontitis in diabetic patients in Syrian population.

Keywords: Periodontitis; Diabetes Mellitus Type II; TNF- $\alpha$; Promoter; Polymorphism.

\begin{abstract}
Abbreviations: TNF- $\alpha$ : Tumor necrosis factor- $\alpha$; DM: Type II Diabetes Mellitus; ChP: Chronic Periodontitis; ChPDM: Chronic Periodontitis With Diabetes Mellitus; SNP: Single Nucleotide Polymorphism; MHC: Major Histocompatibility Complex; CAL: Clinical Attachment Loss; PD: Pocket Depth; BMI: Body Mass Index; HbA1c: Glycated Hemoglobin; RFLP-PCR: Restriction Fragment Length Polymorphism- Polymerase Chain Reaction; OR: Odds Ratio; CI: Confidence Interval; HWE: Hardy-Weinberg Equilibrium; FFA: Free Fatty Acid.
\end{abstract}

\section{Introduction}

Periodontitis is acomplex inflammatory disorder caused by a gram-negative bacterialplaque accumulated on the surfaces of gingiva and teeth. It is induced by immune imbalance between the plaque and host response [1]. The chronic type of periodontitis (ChP) affects up to $50 \%$ of individuals [2]. ChP is defined bybacterial plaque, inflammatory gingiva, formation of periodontal pocket, loss of attachment and alveolar remodeling [3, 4].

Numerous risk factors can impede the immune balance [5], like environmental factors and bad lifestyle habits, systemic diseases such as diabetes, and genetic variables $[1,6,7]$.

Diabetes mellitus Type 2 (DM) is a multifactorial metabolic diseaseincluding hyperglycemia and modifying lipid metabolism. It is caused by inadequate insulin secretion from $\beta$-islets and insulin resistance [8]. Chronic hyperglycemia affects bone formation by tissue oxidative stress [9], and increases the risk of periodontitis in uncontrolled DM subjects [10].

Studies have shown common gene variations between DM and periodontitis. However, this relationship needs more research about the genes that may affect both diseases [11].

Cytokine gene Single Nucleotide Polymorphisms (SNPs) have a crucial role in periodontal health regulation. Tumor necrosis

\section{*Corresponding Author:}

Faten Kafa,

Biochemistry and Microbiology Department, Faculty of Pharmacy, Damascus University, Syria.

E-mail: fatenkafa@yahoo.com

Received: September 19, 2021

Accepted: November 17, 2021

Published: November 20, 2021

Citation: Faten Kafa, Ali Abou Sulaiman, Shaden Haddad. Association of Tumor Necrosis Factor- $\alpha$ Gene Promoter Polymorphisms with Periodontitisin Type II Diabetic Syrian Population. Int J Dentistry Oral Sci. 2021;8(11):5064-5069. doi: http://dx.doi.org/10.19070/2377-8075-210001020

Copyright: Faten $\mathrm{Kafa}^{\circ}$ 2021. This is an open-access article distributed under the terms of the Creative Commons Attribution License, which permits unrestricted use, distribution and reproduction in any medium, provided the original author and source are credited. 
factor- $\alpha(\mathrm{TNF}-\alpha)$ is one of potential proinflammatory cytokines secreted mainly by macrophages.It induces the tissue injury and bone resorption and many inflammatory pathways. It is involved in phagocytosis, polymorphonuclear leukocytes (PMNs)- endothelial cells adhesion, necrosis and apoptosis[12, 13]. Many SNPswithin TNF- $\alpha$ gene associatewithperiodontitis, also can lead to DM by stimulating insulin resistance [14].

The TNF- $\alpha$ gene consists of four exons and three introns located in chromosome 6 , short (p) arm, in the major histocompatibility complex (MHC) class III region $[15,16]$.

Many researches showed that $\mathrm{TNF}-\alpha$ expression and its activity are affected by gene variables, which may increase the risk and severity of periodontitis [17].

An Indian study has reportedthat the distribution difference of $-857 \mathrm{C} / \mathrm{T}$ and $-1031 \mathrm{~T} / \mathrm{C}$ polymorphisms was significantin periodontitis subjects comparing to healthy group [17]. On the other hand,-857T and -1031C alleleswere more frequent in periodontitis groups in Japanese population [18]. Similarly, T allele in -857 polymorphism has significantly enhanced transcriptional activity vs. C allele and tend to be more insulin resistant in an another Japanese study of type 2 diabetic subjects [19].

Many studies have shown that -1031TT genotype might be an important protective factor for ChP Asians. TNF expression by mutant -1031CC genotype was significantly higher than -1031TT genotype. Also,TNF protein secretion could be stimulated by $-1031 \mathrm{~T} / \mathrm{C}$, and elevated cytokine levels may control periodontitis progression [20].

Traditionally, many studies have investigated the association of polymorphisms at $-857 \mathrm{C} / \mathrm{T}$ and $-1031 \mathrm{~T} / \mathrm{C}$ positions with ChP. Nonetheless, studies that examined these polymorphisms in chronic periodontitis with diabetes mellitus (ChPDM) were scarce.

Therefore, the aim of this study is to examine the potential role of TNF- $\alpha$ gene polymorphisms at $-857 \mathrm{C} / \mathrm{T}$ and $-1031 \mathrm{~T} / \mathrm{C}$ positions in the susceptibility to ChP and DM type II in the Syrian population.

\section{Materials and Methods}

\section{Ethics statements}

This study was approved by the Institutional Ethics Committee at Damascus University, and it was conducted in accordance with the Helsinki Declaration. All patients gave their consent about the study purpose and nature.

\section{Study population}

The study is cross sectional enrolled100 Syrian participantsdiagnosed $\mathrm{ChP}$ attending the Periodontology Department of Faculty of Dentistry - Damascus University, 60 of them were type 2 diabetic (ChPDM). Additionally, 40 race/ age-matched healthy subjects $(\mathrm{H})$, and 40 type 2 diabetics $(\mathrm{DM})$ with healthy periodontal tissues were recruited.

\section{Inclusion criteria}

Individualsaged 40 - 70 years, have a minimum of 20 teeth(other than third molars), clinical attachment loss (CAL) $\geq 3 \mathrm{~mm}$ in two interproximal sites, and pocket depth $\mathrm{PD} \geq 4 \mathrm{~mm}$ in $\geq 2$ interproximal sites (on different tooth) [21], and body mass index (BMI) between $19-30.5 \mathrm{~kg} / \mathrm{m}^{2}$. Periodontitis severity was classified depending on the pocket depth (PD) into three degrees: primary $(\mathrm{PD}=4-5 \mathrm{~mm})$, moderate $(6-7 \mathrm{~mm})$, severe $(>7 \mathrm{~mm})$. The type II DM participants were with glycated hemoglobin (HbA1c) $\geq 7 \%$.

\section{Exclusion criteria}

Systemic diseasesthat may affect the immune responses, treatment with antibiotics and/or NSAIDs last 3 months, pregnancy and/ or breast feeding, smokers and alcoholics.

\section{Sample Collection}

From each subject, $3 \mathrm{ml}$ of peripheral blood was collected in EDTA tubes. Genomic DNA wasisolatedby a manual protocol using urea and proteinase K [22]. DNA was quantified by measuring 260nm-absorbance using Nanodrop(Thermo scientific ${ }^{\circ}$, USA), and then stored at $-20^{\circ} \mathrm{C}$ until use.

\section{Genotype determination}

The TNF- $\alpha$ SNPs were genotyped using polymerase chain reaction (PCR) and primers with sequences shown in Table (1). Then PCR products were purified to remove excess salts and electrophorized on agarose gel $2 \%$. According to the digestive results by HincII (-857T mutant allele)and BbsI(-1031C mutant allele) enzymes(Jena Bioscience ${ }^{\circledR}$, Germany), subjects were classified as (TT) homozygotes, (CT) heterozygotes, or (CC) homozygotes.

\section{Statistical analysis}

SPSS Statistical software, version 25 (IBM®, New York, USA) and GraphPad prism (version 9.1.2) were used to process the collected data. Goodness-of-fit was analyzed by Hardy-Weinberg equilibrium. The Chi-squared test was used to determine any association between alleles or genotypes among the four study groups. The effect degree was explicated as an odds ratio (OR) with a $95 \%$ confidence interval (CI), and data was considered significant at $\mathrm{P}$ value $<0.05$.

\section{Results}

Study Groups were age and gender matched. Demographic data are presented in Table (2), which also shows the distribution of $\mathrm{ChP}$ and ChPDMpatients according to sex and disease severity without any significant statistical differences between the study groups $(\mathrm{P}<0.05)$, while differences with $\mathrm{BMI}$ values were significant $(\mathrm{P}<0.001)$. Study Groups were age and gender matched. Demographic data are presented in Table (2), which also shows the distribution of ChP and ChPDMpatients according to sex and disease severity without any significant statistical differences between the study groups $(\mathrm{P}<0.05)$, while differences with $\mathrm{BMI}$ values were significant $(\mathrm{P}<0.001)$. 
Thegenotype and allele frequencieswere in compatible with Hardy-Weinberg Equilibrium (HWE), and there was no significant differences between observed and expected genotypes in eachsubject group $(\mathrm{P}=1.99)$.

Genotypes and alleles frequencies of both SNPs were calculatedamong groups, and shown in the Table (3). By using Chi squared test, the associations between polymorphisms and susciptibility to the diseases (periodontitis and DM) has been tested: $\mathrm{H}$ group versus each group (ChP, DM and ChPDM). The effect degree was expressed as OR with 95\% CI.
In Table (4), the $-857 \mathrm{C} / \mathrm{T}$ SNP in the TNF- $\alpha$ gene promoter was compared between $\mathrm{H}$ group and each other three groups of patients, and showed no significant differences with $\mathrm{ChP}$ patients with and without DM. However, DM subjects carrying the T allele hadsignificantly an over 3-fold risk to develop the disease only without ChP compared with C subjects (adjusted OR 3.116, 95\% CI: 1.184- 8.2, P = 0.019), and CC genotype had an important protective role against diabetes mellitus (adjusted OR 0.321, 95\% CI: 0.122- 0.844, $\mathrm{P}=0.019)$.

Table 1. Primer sequences, PCR annealing temperatures, and products.

\begin{tabular}{|c|c|c|c|}
\hline SNP & Primers & $\begin{array}{l}\text { Annealing Tempera- } \\
\text { ture }\end{array}$ & $\begin{array}{l}\text { PCR product } \\
\text { (bp) }\end{array}$ \\
\hline \multirow{2}{*}{$\begin{array}{c}-857 \mathrm{C} / \mathrm{T} \\
(\mathrm{rs} 1799724)\end{array}$} & $\begin{array}{c}\text { F:5'-AAGTCGAGTATGG- } \\
\text { GGACCCCCCGTTAA-3' }\end{array}$ & \multirow{2}{*}{$60^{\circ} \mathrm{C}$ for $1 \mathrm{~min}$} & $131 \mathrm{bp}$ \\
\hline & $\begin{array}{l}\text { R: 5'-CCCCAGTGTGTG- } \\
\text { GCCATATCTTCTT-3' }\end{array}$ & & $\begin{array}{l}\text { (de Oliveira, Ross } \\
\text { et al. 2015) }\end{array}$ \\
\hline \multirow{2}{*}{$\begin{array}{l}-1031 \mathrm{~T} / \mathrm{C} \\
(\mathrm{rs} 1799964)\end{array}$} & $\begin{array}{l}\text { F:5'-GGGGAGAA- } \\
\text { CAAAAGGATAAG-3' }\end{array}$ & \multirow{2}{*}{$55^{\circ} \mathrm{C}$ for $30 \mathrm{sec}$} & $270 \mathrm{bp}$ \\
\hline & $\begin{array}{l}\text { R: 5'-CCСCATACTC- } \\
\text { GACT'TTCATA-3' }\end{array}$ & & [23] \\
\hline
\end{tabular}

Table 2. Descriptive study results.

\begin{tabular}{|c|c|c|c|c|c|c|}
\hline & $\mathbf{H}$ & ChP & DM & ChPDM & $P$ value \\
\hline \multicolumn{2}{|c|}{$\begin{array}{c}\text { Age } \\
(\mathrm{mean} \pm \mathrm{SD})\end{array}$} & $49.95 \pm 5.953$ & $\begin{array}{c}50.97 \pm \\
7.648 \\
\end{array}$ & $52.03 \pm 7.83$ & $49.55 \pm 6.531$ & $0.3297 \mathrm{~b}$ \\
\hline \multicolumn{2}{|c|}{$\begin{array}{c}\text { Male/Female } \\
\mathrm{N}(\%)\end{array}$} & $20(50) / 20(50)$ & $\begin{array}{c}22(55) / \\
18(45) \\
\end{array}$ & $20(50) / 20(50)$ & $\begin{array}{l}35(58.33) / \\
25(41.66)\end{array}$ & $0.805 \mathrm{a}$ \\
\hline \multirow{3}{*}{$\begin{array}{l}\text { ChP } \\
\text { Severity }\end{array}$} & Severe & NA & 21 & NA & 29 & \multirow{3}{*}{$0.9178 \mathrm{a}$} \\
\hline & Moderate & NA & 10 & $\mathrm{NA}$ & 16 & \\
\hline & Primary & $\mathrm{NA}$ & 9 & NA & 15 & \\
\hline \multicolumn{2}{|c|}{ BMI $(\mathrm{kg} / \mathrm{m} 2)$} & $22.47 \pm 1.52$ & $\begin{array}{c}23.04 \pm \\
1.467\end{array}$ & $28.06 \pm 1.47$ & $28.02 \pm 1.57$ & $<0.0001 \mathrm{~b}$ \\
\hline
\end{tabular}

a: chi squared test

b: one way ANOVA test

Table 3. The genotypes and alleles frequencies of $-857 \mathrm{C} / \mathrm{T}$ and $-1031 \mathrm{~T} / \mathrm{C}$.

\begin{tabular}{|c|c|c|c|c|c|c|c|c|c|}
\hline Genotypes & H & ChP & DM & ChPDM & Genotypes & H & ChP & DM & ChPDM \\
\hline -857C/T & $(\mathrm{N}=40)$ & $(\mathrm{N}=40)$ & $(\mathrm{N}=40)$ & $(\mathrm{N}=60)$ & $-1031 T / C$ & $(\mathrm{~N}=40)$ & $(\mathrm{N}=40)$ & $(\mathrm{N}=40)$ & $(\mathrm{N}=60)$ \\
\hline $\mathbf{C C}$ & $19(47.5 \%)$ & $15(37.5 \%)$ & $9(22.5 \%)$ & $18(30 \%)$ & $\mathbf{T T}$ & $29(72.5 \%)$ & $22(55 \%)$ & $23(57.5 \%)$ & $28(46.67 \%)$ \\
\hline CT & $16(40 \%)$ & $21(52.5 \%)$ & $23(57.5 \%)$ & $29(48.33 \%)$ & $\mathbf{C T}$ & $10(25 \%)$ & $14(35 \%)$ & $12(30 \%)$ & $23(38.33 \%)$ \\
\hline TT & $5(12.5 \%)$ & $4(10 \%)$ & $8(20 \%)$ & $13(21.67 \%)$ & $\mathbf{C C}$ & $1(2.50 \%)$ & $4(10 \%)$ & $5(12.5 \%)$ & $9(15 \%)$ \\
\hline Alleles & & & & & Alleles & & & & \\
\hline C & $54(67.5 \%)$ & $51(63.75 \%)$ & $41(51.25 \%)$ & $65(54.17 \%)$ & $\mathbf{T}$ & $68(85 \%)$ & $58(72.5 \%)$ & $58(72.5 \%)$ & $79(65.83 \%)$ \\
\hline T & $26(32.5 \%)$ & $29(36.25 \%)$ & $39(48.75 \%)$ & $55(45.83 \%)$ & $\mathbf{C}$ & $12(15 \%)$ & $22(27.5 \%)$ & $22(27.5 \%)$ & $41(34.17 \%)$ \\
\hline
\end{tabular}

Table 4 . The genotypes and alleles frequencies of $-857 \mathrm{C} / \mathrm{T}$ according the study groups.

\begin{tabular}{|c|c|c|c|c|c|c|c|c|c|c|c|c|}
\hline$-857 \mathrm{C} / \mathrm{T}$ & \multicolumn{3}{|c|}{$\mathrm{H}$ vs $\mathrm{ChP}$} & \multicolumn{3}{|c|}{ H vs DM } & \multicolumn{3}{|c|}{ H vs ChPDM } & \multicolumn{3}{|c|}{ ChP vs ChPDM } \\
\hline Genotypes & p* & OR & CI $(95 \%)$ & p* & OR & CI $(95 \%)$ & p* & OR & CI $(95 \%)$ & p* & OR & CI $(95 \%)$ \\
\hline $\mathrm{CC}$ & 0.499 & 0.737 & $0.304-1.787$ & 0.019 & 0.321 & $0.122-0.844$ & 0.076 & 0.474 & $0.206-1.087$ & 0.435 & 0.714 & $0.308-1.686$ \\
\hline $\mathrm{CT}$ & 0.262 & 1.658 & $0.683-4.022$ & 0.117 & 2.029 & $0.833-4.945$ & 0.511 & 1.313 & $0.583-2.953$ & 0.683 & 0.846 & $0.395-1.955$ \\
\hline TT & 0.456 & 0.568 & $0.126-2.554$ & 0.363 & 1.75 & $0.519-5.903$ & 0.176 & 2.13 & $0.701-6.476$ & 0.128 & 2.489 & $0.818-7.406$ \\
\hline \multicolumn{13}{|l|}{ Alleles } \\
\hline $\mathrm{C}$ & 0.456 & 1.762 & $0.392-7.929$ & 0.363 & 0.571 & $0.169-1.928$ & 0.176 & 0.469 & $0.154-1.427$ & 0.128 & 0.672 & $0.373-1.183$ \\
\hline $\mathrm{T}$ & 0.499 & 1.357 & $0.559-3.292$ & 0.019 & 3.116 & $1.184-8.2$ & 0.076 & 2.111 & $0.92-4.845$ & 0.435 & 1.488 & $0.845-2.681$ \\
\hline
\end{tabular}

(*) Chi squared, Bold means a significant difference 
Restriction products of HincII restriction enzyme on $2 \%$ gel electrophoresis are shown in Figure (1).

BbsI enzyme restriction fragments are electrophoresed on agarose gel 2\% (Figure 2), and it was confirmed in the Table (5) that subjects with -1031CC genotype had almost 7-fold risk to develop periodontitis together with $\mathrm{DM}(\mathrm{OR}=6.882,95 \% \mathrm{CI}: 0.836-56.6$, $\mathrm{P}=0.041$ ), while there were not a significant difference between healthy group and each disease alone.

Then the frequencies of genotypes were calculated according to disease severity, that the severity was divided to three groups: severe, moderate, and primary. In $-857 \mathrm{C} / \mathrm{T}$ SNP, there were no significant differences between these frequencies and groups of severity ( $p>0.05$ ) in ChP group, while the difference was significant between TT genotype and severity in ChPDM subjects, that this genotype is exist in primary subjects in significantly higher percentage $(p=0.039)$ Table $(6)$.

Also, in -1031T/C SNP, there was a significant difference between severity and frequencies of wild genotype TT in ChP subjects with $\mathrm{DM}$,that it may have a protective role against periodontitis

Figure 1. Photograph of the PCR-RFLP products of-857C/T SNP in TNF- $\alpha$ promoter gene on 2\%agarose gel Line M: Marker, lines CC: homozygote wild genotype ( 131bp), line CT: heterozygote genotype ( 131bp, $\sim 107 \mathrm{bp})$, and line TT: homozygote mutant genotype ( 107bp).

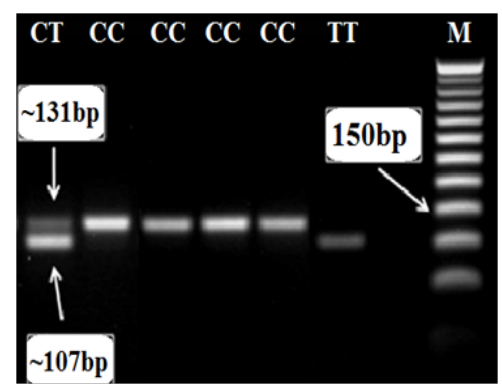

Figure 2. PCR-RFLP products of $-1031 \mathrm{~T} / \mathrm{C}$ in TNF- $\alpha$ promoter gene on $2 \%$ agarose gel. Line M: Marker, lines TT: homozygote wild genotype ( 270bp), lines CT: heterozygote genotype ( 270, 159, 111bp), and lines CC: homozygote mutant genotype ( 159, $111 \mathrm{bp})$.

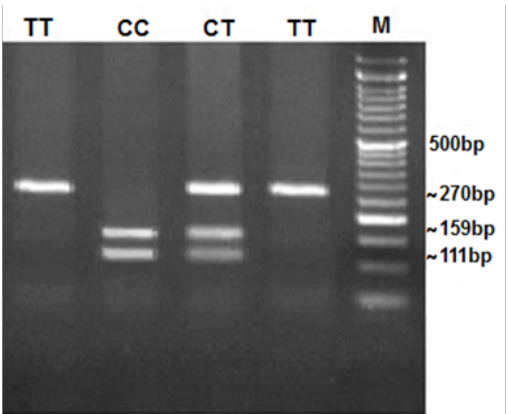

Table 5. The genotypes and alleles frequencies of $-1031 \mathrm{~T} / \mathrm{C}$ according the study groups.

\begin{tabular}{|c|c|c|c|c|c|c|c|c|c|c|c|c|}
\hline -1031T/C & \multicolumn{3}{|c|}{ H vs ChP } & \multicolumn{3}{c|}{ H vs DM } & \multicolumn{3}{c|}{ H vs ChPDM } & \multicolumn{3}{c|}{ ChP vs ChPDM } \\
\hline Genotypes & $\mathbf{p}^{*}$ & OR & CI (95\%) & $\mathbf{p}^{*}$ & $\mathbf{O R}$ & $\mathbf{C I} \mathbf{( 9 5 \% )}$ & $\mathbf{p}^{*}$ & $\mathbf{O R}$ & $\mathbf{C I} \mathbf{9 5 \% )}$ & $\mathbf{p}^{*}$ & OR & CI $\mathbf{( 9 5 \% )}$ \\
\hline TT & 0.104 & 0.464 & $0.182-1.178$ & 0.16 & 0.513 & $0.201-1.308$ & 0.011 & 0.332 & $0.141-0.784$ & 0.414 & 0.716 & $0.321-1.599$ \\
\hline CT & 0.329 & 1.615 & $0.614-4.247$ & 0.617 & 1.286 & $0.48-3.442$ & 0.165 & 1.865 & $0.77-4.518$ & 0.735 & 1.154 & $0.502-2.654$ \\
\hline CC & 0.166 & 4.33 & $0.462-40.6$ & 0.09 & 5.571 & $0.62-50.03$ & 0.041 & 6.882 & $0.836-56.6$ & 0.466 & 1.588 & $0.454-5.558$ \\
\hline Alleles & & & & & & & & & & & & \\
\hline T & 0.166 & 0.231 & $0.025-2.163$ & 0.09 & 0.179 & $0.02-1.612$ & 0.041 & 0.145 & $0.018-1.196$ & 0.466 & 0.63 & $0.18-2.204$ \\
\hline C & 0.104 & 2.157 & $0.849-5.481$ & 0.16 & 1.949 & $0.765-4.965$ & 0.011 & 3.013 & $1.275-7.117$ & 0.414 & 1.397 & $0.626-3.119$ \\
\hline
\end{tabular}

(*) Chi squared, Bold means a significant difference.

Table 6. The -857C/T and -1031T/C genotype frequencies according to disease severity.

\begin{tabular}{|c|c|c|c|c|c|c|c|c|c|c|}
\hline & $\begin{array}{l}\text { Genotype } \\
-857 \mathrm{C} / \mathrm{T}\end{array}$ & Severe & Moderate & Primary & $\mathbf{P} *$ & $\begin{array}{l}\text { Genotype } \\
-1031 T / C\end{array}$ & Severe & Moderate & Primary & $\mathbf{P *}$ \\
\hline \multirow[t]{3}{*}{$\mathrm{ChP}$} & $\mathrm{CC}$ & $9(42.86 \%)$ & $4(40 \%)$ & $2(22.22 \%)$ & 0.876 & TT & $12(57.14 \%)$ & $6(60 \%)$ & $4(44.44 \%)$ & 0.17 \\
\hline & CT & $10(47.62 \%)$ & $5(50 \%)$ & $6(66.67 \%)$ & 0.53 & CT & $7(33.33 \%)$ & $3(30 \%)$ & $4(44.44 \%)$ & 0.277 \\
\hline & TT & $2(9.52 \%)$ & $1(10 \%)$ & $1(11.11 \%)$ & 0.733 & $\mathrm{CC}$ & $2(9.53 \%)$ & $1(10 \%)$ & $1(11.11 \%)$ & 0.201 \\
\hline \multirow[t]{3}{*}{ ChPDM } & $\mathrm{CC}$ & $10(34.48 \%)$ & $5(31.25 \%)$ & $3(20 \%)$ & 0.255 & TT & $14(48.28 \%)$ & $6(37.50 \%)$ & $8(53.34 \%)$ & 0.042 \\
\hline & C'T & $14(48.27 \%)$ & $9(56.25 \%)$ & $6(40 \%)$ & 0.552 & CT & $12(41.38 \%)$ & $6(37.50 \%)$ & $5(33.33 \%)$ & 0.527 \\
\hline & TT & $5(17.24 \%)$ & $2(12.50 \%)$ & $6(40 \%)$ & 0.039 & $\mathrm{CC}$ & $3(10.34 \%)$ & $4(25 \%)$ & $2(13.33 \%)$ & 0.067 \\
\hline
\end{tabular}


progression $(p=0.042)$.

\section{Discussion}

Periodontitis is a multifacetedinfection triggered by microbial plaque, that induces TNF- $\alpha$ expression. TNF- $\alpha$ can affect the immune responsesby alteration of vascular endothelial function, and modifying the preservative equilibrium and endothelium permeability. It is considered as a risk factor of systemic inflammation diseases with vascular dysfunction, such as diabetes [24], as well as other environmental and / or behavioral factors like mouth hygiene [25].

Many studies concerning the association between TNF- $\alpha$ gene SNPs and susceptibility to periodontitis are available, but the results were conflicting [20].

In this study, we had an attempt to find genetic association between TNF- $\alpha$ and periodontal disease with and without DM.Cytokine transcription and production levels may be influenced by their gene polymorphisms, which in turn may induce the susceptibility or resistance to several diseases, so this study has involved two polymorphisms in TNF- $\alpha$ gene promoter.

Studies investigating -857C/T and -1031T/C SNPs in both periodontitis and DM are rare. Literature review revealed that this study is the first in Syria that evaluates the association between TNF gene promoter SNPs and susceptibility to ChP in diabetic patients.

This study has shown a significant difference between the groups in -857CC genotype frequenciesin DM patients, but not in both diseases. The subjects carrying the $T$ allele were significantly more likely to develop DM only without periodontitis compared with C subjects.

Also, at $-1031 \mathrm{~T} / \mathrm{C}$ there was a significant differencein genotype CC between healthy group and ChPDM group, and subjects with risk allele $\mathrm{C}$ were more likely to develop periodontitis together with DM.

These findings are in line with many other studies that also foundno correlation between ChP subjects and both genotypes -857C/ $\mathrm{T}$ and $-1031 \mathrm{~T} / \mathrm{C}$ compared to healthy group in Indian population [17]. In Japanese population'T allele of $-857 \mathrm{C} / \mathrm{T}$ and $-1031 \mathrm{C}$ allele were more elevated in periodontitis groups [18]. Also in Japanese with DM type II, the gene promoter of TNF with -857Tallele significantly stimulated transcriptional activity more than the $-857 \mathrm{C}$ promoter. Patients with TNF- $\alpha-857 \mathrm{~T}$ allele tend to be more insulin resistant [19]. In Chinese and Asians, -1031CC genotype was significantly higher in ChPgroup compared with $\mathrm{H}$ group, while there were a low level of association of $-857 \mathrm{C} / \mathrm{T}$ polymorphism with susceptibility to $\mathrm{ChP}$ [26-28]. These results didn't match with those in South Indian population, that $-1031 \mathrm{~T} / \mathrm{C}$ polymorphism had no association with ChP susceptibility [29].

Several lines of evidence have showed that variants of -1031 and -857 alleles have been related to elevated $\mathrm{TNF}-\alpha$ secretion $[12,30]$, and actas a critical factor in susceptibility of DM and its severity [18]. TNF- $\alpha$ inhibits adipose lipoprotein lipase activity, and induces hepatic lipogenesis, leading to excess metabolism of plasma lipids. It stimulates lipolysis and inhibits the uptake of free fatty acid (FFA). High FFA production can cause gluconeogenesis induction, and finally hyperglycemia [14].

TNF- $\alpha$ expression, as a proinflammatory cytokine, has a key role in periodontitis development, and raises resorption degree of the alveolar bone and periodontal cell proliferation [12].

Even though it is known that-857C/T SNP can directly affect the transcription efficiency of $\mathrm{TNF}-\alpha$, its functional effects have been contentious on TNF- $\alpha$ cellular level. Recently, van Heel et al. study suggested that blood TNF- $\alpha$ stimulates lipopoly saccharide production in $-857 \mathrm{CC}$ genotypes more than mutant T-allele carriers. The transcription factor OTC1 binds to (ATGAAGAC) sequence in TNF- $\alpha$ promoter from _858 to _ 851 position, only with $\mathrm{T}$ allele in -857 site, to inhibit the function of promoter [31]. $-1031 \mathrm{~T} / \mathrm{C}$ polymorphism could be a therapeutic prediction of the response to TNF- $\alpha$ blockers [32].

Jain, P. et al showed that ChP increases serum TNF- $\alpha$ levels diabetic patients [33], so we are still working on finding the link between -1031 and -857 SNPs and its salivary levels in our study groups.

Within the limits of this study, it can be suggested that TNF- $\alpha$ $-1031 \mathrm{~T} / \mathrm{C}$ SNP raises the risk of periodontitis, while there were no association between $-857 \mathrm{C} / \mathrm{T}$ and periodontitis in diabetic patients in Syrian population.

\section{Acknowledgment}

The study has been funded by Damascus University.

\section{References}

[1]. Stabholz, A., W.A. Soskolne, and L. Shapira, Genetic and environmental risk factors for chronic periodontitis and aggressive periodontitis. Periodontol 2000, 2010. 53: p. 138-53.

[2]. Nazir MA. Prevalence of periodontal disease, its association with systemic diseases and prevention. Int J Health Sci (Qassim). 2017 Apr-Jun;11(2):72-80. PubMed PMID: 28539867.

[3]. Wiebe CB, Putnins EE. The periodontal disease classification system of the American Academy of Periodontology--an update. J Can Dent Assoc. 2000 Dec;66(11):594-7. PubMed PMID: 11253351.

[4]. Armitage GC. Development of a classification system for periodontal diseases and conditions. Ann Periodontol. 1999 Dec;4(1):1-6. doi: 10.1902/ annals.1999.4.1.1. PubMed PMID: 10863370.

[5]. El Jilani MM, Mohamed AA, Zeglam HB, Alhudiri IM, Ramadan AM, Saleh SS, Elkabir M, Amer IB, Ashammakhi N, Enattah NS. Association between vitamin $\mathrm{D}$ receptor gene polymorphisms and chronic periodontitis among Libyans. Libyan J Med. 2015 Jan;10(1):26771. PubMed PMID: 28349804.

[6]. Beukers NG, van der Heijden GJ, van Wijk AJ, Loos BG. Periodontitis is an independent risk indicator for atherosclerotic cardiovascular diseases among 60174 participants in a large dental school in the Netherlands. J Epidemiol Community Health. 2017 Jan;71(1):37-42. doi: 10.1136/jech-2015206745. Epub 2016 Aug 8. PubMed PMID: 27502782.

[7]. Kafa F, A Abou Sulaiman, S Haddad. Association between vitamin D receptor foki polymorphism and chronic periodontitis in Syrian population. International Journal of Pharmaceutical Sciences and Research. 2019;10(3):1336-1341.

[8]. Wu YY, Xiao E, Graves DT. Diabetes mellitus related bone metabolism and periodontal disease. Int J Oral Sci. 2015 Jun 26;7(2):63-72. PubMed PMID: 25857702.

[9]. Abdellatif HM, Binshabaib MS, Shawky HA, ALHarthi SS. Association between Periodontitis and Genetic Polymorphisms in Interleukins among Patients with Diabetes Mellitus. Dent J (Basel). 2021 Apr 18;9(4):45. PubMed PMID: 33919509. 
[10]. Sharma N, Joseph R, Arun R, Chandni R, Srinivas KL, Banerjee M. Cytokine gene polymorphism (interleukin-1 $\beta+3954$, Interleukin-6 [-597/-174] and tumor necrosis factor- $\alpha-308)$ in chronic periodontitis with and without type 2 diabetes mellitus. Indian J Dent Res. 2014 May-Jun;25(3):375-80. PubMed PMID: 25098998.

[11]. Cirelli T, Nepomuceno R, Rios ACS, Orrico SRP, Cirelli JA, Theodoro LH, Barros SP, Scarel-Caminaga RM. Genetic polymorphisms in the Interleukins IL1B, IL4, and IL6 are associated with concomitant periodontitis and type 2 diabetes mellitus in Brazilian patients. J Periodontal Res. 2020 Dec;55(6):918-930. doi: 10.1111/jre.12784. Epub 2020 Jul 9. PubMed PMID: 32648256.

[12]. Majumder P, Thou K, Bhattacharya M, Nair V, Ghosh S, Dey SK. Association of tumor necrosis factor- $\alpha$ (TNF- $\alpha$ ) gene promoter polymorphisms with aggressive and chronic periodontitis in the eastern Indian population. Biosci Rep. 2018 Jul 31;38(4):BSR20171212. PubMed PMID: 29449347.

[13]. Grover HS, Saini R, Bhardwaj P, Bhardwaj A. Cytokines and other inflammatory mediators in periodontal health and disease. Indian Journal of Oral Health and Research. 2016 Jan 1;2(1):12.

[14]. Ayelign B, Genetu M, Wondmagegn T, Adane G, Negash M, Berhane N. TNF- $\alpha$ (-308) Gene Polymorphism and Type 2 Diabetes Mellitus in Ethiopian Diabetes Patients. Diabetes Metab Syndr Obes. 2019 Nov 28;12:24532459. PubMed PMID: 31819571.

[15]. Molvarec A, Jermendy A, Nagy B, Kovács M, Várkonyi T, Hupuczi P, Prohászka Z, Rigó J Jr. Association between tumor necrosis factor (TNF)alpha G-308A gene polymorphism and preeclampsia complicated by severe fetal growth restriction. Clin Chim Acta. 2008 Jun;392(1-2):52-7. PubMed PMID: 18396154.

[16]. Salles AG, Antunes LAA, Carvalho PA, Küchler EC, Antunes LS. Association Between Apical Periodontitis and TNF- $\alpha-308$ G>A Gene Polymorphism: A Systematic Review and Meta-Analysis. Braz Dent J. 2017 SepOct;28(5):535-542. PubMed PMID: 29215675.

[17]. Majumder P, Thou K, Bhattacharya M, Nair V, Ghosh S, Dey SK. Association of tumor necrosis factor- $\alpha$ (TNF- $\alpha$ ) gene promoter polymorphisms with aggressive and chronic periodontitis in the eastern Indian population. Biosci Rep. 2018 Jul 31;38(4):BSR20171212. PubMed PMID: 29449347.

[18]. Soga Y, Nishimura F, Ohyama H, Maeda H, Takashiba S, Murayama Y. Tumor necrosis factor-alpha gene (TNF-alpha) -1031/-863, -857 single-nucleotide polymorphisms (SNPs) are associated with severe adult periodontitis in Japanese. J Clin Periodontol. 2003 Jun;30(6):524-31. PubMed PMID: 12795791.

[19]. Ohara M, Maesawa C, Takebe N, Takahashi T, Yamashina M, Ono M, Matsui M, Sasai T, Honma H, Nagasawa K, Fujiwara F, Kajiwara T, Taneichi $\mathrm{H}$, Takahashi K, Satoh J. Different susceptibility to insulin resistance and fatty liver depending on the combination of TNF- $\alpha$ C-857T and adiponectin G+276T gene polymorphisms in Japanese subjects with type 2 diabetes. Tohoku J Exp Med. 2012 Feb;226(2):161-9. PubMed PMID: 22327199.

[20]. Xu L, Liu C, Zheng Y, Huang Y, Zhong Y, Zhao Z, Ma N, Zhang Z, Zhang L. Association of TNF- $\alpha-308 \mathrm{G} / \mathrm{A},-238 \mathrm{G} / \mathrm{A},-863 \mathrm{C} / \mathrm{A},-1031 \mathrm{~T} / \mathrm{C},-857 \mathrm{C} / \mathrm{T}$ polymorphisms with periodontitis susceptibility: Evidence from a metaanalysis of 52 studies. Medicine (Baltimore). 2020 Sep 4;99(36):e21851. PubMed PMID: 32899013.
[21]. Eke PI, Page RC, Wei L, Thornton-Evans G, Genco RJ. Update of the case definitions for population-based surveillance of periodontitis. J Periodontol. 2012 Dec;83(12):1449-54. PubMed PMID: 22420873; PMCID.

[22]. Chacon Cortes DF, Griffiths L. Methods for extracting genomic DNA from whole blood samples: current perspectives. Journal of Biorepository Science for Applied Medicine. 2014;2014(2):1-9.

[23]. Bonyadi M, Abdolmohammadi R, Jahanafrooz Z, Somy MH, Khoshbaten M. TNF-alpha gene polymorphisms in Iranian Azari Turkish patients with inflammatory bowel diseases. Saudi J Gastroenterol. $2014 \mathrm{Mar}-$ Apr;20(2):108-12. PubMed PMID: 24705148.

[24]. Kumar G, Ponnaiyan D, Parthasarathy H, Tadepalli A, Veeramani S. Evaluation of Endocan and Tumor Necrosis Factor- $\alpha$ as Inflammatory Biomarkers in Type 2 Diabetes and Periodontal Disease. Genet Test Mol Biomarkers. 2020 Jul;24(7):431-435. PubMed PMID: 32513032.

[25]. Petrovic SM, Nikolic N, Toljic B, Arambasic-Jovanovic J, Milicic B, Milicic T, Jotic A, Vidakovic M, Milasin J, Pucar A. The association of tumor necrosis factor alpha, lymphotoxin alpha, tumor necrosis factor receptor 1 and tumor necrosis factor receptor 2 gene polymorphisms and serum levels with periodontitis and type 2 diabetes in Serbian population. Arch Oral Biol. 2020 Dec;120:104929. PubMed PMID: 33091664.

[26]. Yang W, Jia Y, Wu H. Four tumor necrosis factor alpha genes polymorphisms and periodontitis risk in a Chinese population. Hum Immunol. 2013 Dec;74(12):1684-7. PubbMed PMID: 23973890.

[27]. Heidari Z, Moudi B, Mahmoudzadeh-Sagheb H. Immunomodulatory factors gene polymorphisms in chronic periodontitis: an overview. BMC Oral Health. 2019 Feb 12;19(1):29. PubMed PMID: 30755190.

[28]. Xu L, Liu C, Zheng Y, Huang Y, Zhong Y, Zhao Z, Ma N, Zhang Z, Zhang L. Association of TNF- $\alpha-308 \mathrm{G} / \mathrm{A},-238 \mathrm{G} / \mathrm{A},-863 \mathrm{C} / \mathrm{A},-1031 \mathrm{~T} / \mathrm{C},-857 \mathrm{C} / \mathrm{T}$ polymorphisms with periodontitis susceptibility: Evidence from a metaanalysis of 52 studies. Medicine (Baltimore). 2020 Sep 4;99(36):e21851. PubMed PMID: 32899013.

[29]. Lavu V, Venkatesan V, Bhaskar LV, Priyanka V, Kumarasamy P, Durairaj Paul SF, Rao SR. Polymorphic Regions in Fc Gamma Receptor and Tumor Necrosis Factor- $\alpha$ Genes and Susceptibility to Chronic Periodontitis in a Cohort From South India. J Periodontol. 2016 Aug;87(8):914-22. PubMed PMID: 27063995.

[30]. Banerjee M, Saxena M. Genetic polymorphisms of cytokine genes in type 2 diabetes mellitus. World J Diabetes. 2014 Aug 15;5(4):493-504. PubMed PMID: 25126395.

[31]. Kang CP, Lee KW, Yoo DH, Kang C, Bae SC. The influence of a polymorphism at position -857 of the tumour necrosis factor alpha gene on clinical response to etanercept therapy in rheumatoid arthritis. Rheumatology $(\mathrm{Ox}$ ford). 2005 Apr;44(4):547-52. PubMed PMID: 15695296.

[32]. Yang W, Jia Y, Wu H. Four tumor necrosis factor alpha genes polymorphisms and periodontitis risk in a Chinese population. Hum Immunol. 2013 Dec;74(12):1684-7. PubMed PMID: 23973890.

[33]. Jain P, Ved A, Dubey R, Singh N, Parihar AS, Maytreyee R. Comparative Evaluation of Serum Tumor Necrosis Factor $\alpha$ in Health and Chronic Periodontitis: A Case-Control Study. Contemp Clin Dent. 2020 OctDec;11(4):342-349. PubMed PMID: 33850400. 